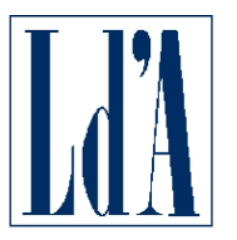

CENTRO STUDI LUCA D'AGLIANO

WWW.DAGLIANO.UNIMI.IT

\author{
CENTRO STUDI LUCA D'AGLIANO \\ DEVELOPMENT STUDIES WORKING PAPERS
}

N. 354

October 2013

Employment Protection Legislation, Capital Investment and Access to Credit: Evidence from Italy

\author{
Federico Cingano* \\ Marco Leonardi** \\ Julián Messina*** \\ Giovanni Pica****
}

* Bank of Italy

** University of Milan, Iza and Centro Studi Luca d'Agliano *** World Bank

**** University of Salerno, CSEF and Centro Studi Luca d'Agliano 


\title{
Employment Protection Legislation, Capital Investment and Access to Credit: Evidence from Italy*
}

\author{
Federico Cingano $^{\dagger} \quad$ Marco Leonardi ${ }^{\ddagger} \quad$ Julián Messina $^{\S} \quad$ Giovanni Pica
}

July 18, 2013

\begin{abstract}
Employment protection may affect both productivity and capital investment because higher adjustments costs hamper allocative efficiency and may therefore affect both the optimal capitallabor input mix and total factor productivity. To estimate the impact of dismissal costs on capital deepening and productivity we exploit a reform that introduced unjust-dismissal costs in Italy for firms below 15 employees, leaving firing costs unchanged for bigger firms. We provide evidence that the increase in firing costs induced capital deepening and a decline in total factor productivity in small firms relative to larger firms after the reform. We also find that capital deepening is more pronounced at the low-end of the capital distribution - where the reform arguably hit harder and among firms endowed with a larger amount of liquid resources, that have more room to react thanks to an easier access to the credit market. Our results also indicate that the EPL reform reduced the probability to access the credit market, possbily because stricter EPL reduces both the value of the firm and the amount of internal resources that the firm can pledge as collateral against lenders.
\end{abstract}

Keywords: Capital Deepening, Severance Payments, Regression Discontinuity Design, Financial Market Imperfections, Credit Constraints.

JEL Classification: J65, G31, D24.

${ }^{*}$ We are grateful to seminar participants at the University of Milan, the University of Naples Federico II, the EALE (2012) and EEA (2013) conference for useful suggestions. Giovanni Pica gratefully acknowledges support from the Europlace Institut of Finance (Project: Finance and Labour, 2011). The usual disclaimer applies.

${ }^{\dagger}$ Bank of Italy. E-mail: federico.cingano@bancaditalia.it.

${ }^{\ddagger}$ University of Milan and IZA. E-mail: marco.leonardi@unimi.it.

${ }^{\S}$ World Bank, University of Girona and CSEF. E-mail: jmessina@worldbank.org.

`University of Salerno, CSEF and Centro Luca D'Agliano. E-mail: gpica@unisa.it. 


\section{Introduction}

If dismissal protections cannot be undone by Coasean bargaining, theory predicts that Employment Protection Legislation (EPL) acts as a tax on both hiring and firing, reducing accessions and separations with an ambiguous final effect on the employment level. The reason is that firing costs provide incentives to retain workers whose wage exceeds their productivity during bad times and not to hire workers whose wage lies below their productivity during good times (Bentolila and Bertola, 1990). While there is a large body of evidence confirming this theoretical prediction (see the recent review by Skedinger, 2011), less is known about the impact of dismissal costs on capital deepening and productivity. A small but growing empirical literature has recently started to analyze the effects of EPL on capital intensity and productivity going beyond country- or sector-level data. Autor et al. (2007) exploit U.S. cross-state variation in the adoption of wrongful-discharge protection norms and find that capital deepening is increased while TFP is reduced. Cingano et. al. (2010) use a large panel of European firms and find instead a negative effect of EPL on capital per worker; they also find that the effect is more severe in low-cash and small firms that are likely to be financially constrained 1

One reason for the paucity of studies on the effects of EPL on capital deepening and productivity is that, while theory offers clear predictions regarding the effects on job turnover, it provides little guidance on the effects on the capital-labor ratio and on productivity.

In competitive models with no financial and labor market frictions, an increase in EPL is expected to raise the cost of labor and induce capital-labor substitution, distorting production choices and reducing allocative efficiency (Autor, 2007); however, the effect may be reversed in the long run when firms can adapt their production techniques and adopt more capital-intensive technologies (Koeniger and Leonardi, 2007; Beaudry and Green, 2007; Alesina and Zeira, 2006; Caballero and Hammour, 1998).

In models with labor market frictions and wage bargaining, stricter EPL strengthens the bargaining power of insider workers and exacerbates the "hold-up" problem typical of investment decisions, reducing the stock of capital per worker (Bentolila and Dolado, 1994; Garibaldi and Violante, 2005; Janiak and Wasmer, 2013). Recently, Janiak and Wasmer (2013) show that also in matching models

\footnotetext{
${ }^{1}$ The empirical literature on EPL has mostly concentrated on the effects on employment flows. See among others, Autor (2003); Autor et al. (2004) and (2006), Kugler and Saint-Paul (2004); Boeri and Jimeno (2005); Kugler and Pica (2008); Bauer et al. (2007); Marinescu (2009). A neighboring literature provides mixed results on the impact of EPL on wages and labor costs: Martins (2009), Bird and Knopf (2009), Cervini Plá et al. (2010), Leonardi and Pica (2013) find a negative relationship; Van der Wiel (2010) finds a positive relationship while Autor et al. (2006) finds mainly insignificant results.
} 
with intrafirm bargaining à la Stole and Zwiebel (1996a, 1996b), the relationship between EPL and capital intensity is monotonic and usually decreasing. It can be positive only under the assumption of complementarity between physical capital and firm-specific human capital: EPL raises the employment share of senior workers with high firm-specific human capital and, by complementarity, this provides incentives for firms to increase investment in physical capital. The implication of the model, supported by cross-country evidence, is an inverse U-shaped relationship between EPL and investment in physical capital: positive for investment at low values of EPL, and negative for investment at higher values.

Overall, the theoretical impact of EPL on capital-labor ratios is ambiguous and depends on the modelling assumptions. So it is for labor productivity: if dismissal protections induce firms to retain unproductive workers and/or to reduce the innovation rate and/or workers' effort, labor productivity is bound to decline. Conversely, stricter EPL may raise aggregate productivity by driving inefficient firms out of the market and by promoting firms' and workers' willingness to engage in training activities because of increased job stability; finally, it may lead to a favorable compositional shift in the productivity of the employed workforce as firms may screen new hires more stringently. Thus, there are potentially various offsetting mechanisms through which EPL may affect productivity. Which one prevails is an empirical matter $2^{2}$

Our contribution is twofold. First, and differently from the previous papers, our exercise exploits within-country variation using an Italian reform that raised firing costs for firms with fewer than 15 employees relative to the cost for other firms. Until 1990 the Italian labor code provided a sharp discontinuity in the application of EPL, with no protection for workers employed in small firms below the 15 employee threshold and high protection for those employed in firms above the threshold. In July 1990, severance payments were increased from zero to between 2.5 and 6 months of pay for firms with 15 or fewer employees, and left unchanged for firms with more than 15 employees. This allows estimating the impact of EPL on firm level outcomes contrasting changes in the outcomes of interest for firms below the 15 employees threshold (treatment group) to contemporaneous changes for firms above the threshold (control group). We use a Regression Discontinuity Design combined with a difference-in-difference approach in order to identify the average causal effect of the EPL reform. The inclusion of firm fixed effects accounts for all possible unobserved time-invariant factors that influence

\footnotetext{
${ }^{2}$ Some papers suggest a negative effect of EPL on productivity through lower workers' effort or less innovation: Bartelsman and Hinloopen (2005), Saint-Paul (2002), Wasmer (2006), Ichino and Riphahn (2005) and Riphahn (2005). Other papers suggest a positive relationship: Belot et al. (2007), Lagos (2006), Bertola (2004), Poschke (2007).
} 
the decision of the firm to stay above or below the 15 employees threshold while industry-year dummies absorb time-varying industry-specific shocks.

Our second contribution is probably the most innovative: we use balance sheet information drawn from a large Italian firm-level data set which allows us to measure accurately firms' financial conditions and to study how firms' liquidity affects the response to the change in EPL. The theoretical literature is virtually silent on the effects of the interaction between EPL and financial market imperfections and there are very few empirical studies (limited to cross-country variation) on the effects of EPL on investment and productivity depending on the ability of the firm to access the credit market. The joint impact of credit and labor market imperfections on investment has been theoretically analyzed in Rendon (2004) and in Wasmer and Weil (2004), who showed that job creation is limited by financing constraints even in the presence of a flexible labor market. Claessens and Ueda (2008), Calcagnini et al. (2009) and Cingano et al. (2010) provide evidence of the joint influence of imperfect financial and labor markets on investment relying on cross-country or U.S. cross-state variation in EPL 3

Results - largely confirmed by an extensive set of robustness checks - suggest that the 1990 Italian EPL reform reduced Total Factor Productivity (TFP), raised capital intensity and had nearly no impact on value added, skill composition of the workforce and year-to-year job flows. This is in line with Autor et al. (2007) who find that the adoption of wrongful-discharge protection norms in U.S.

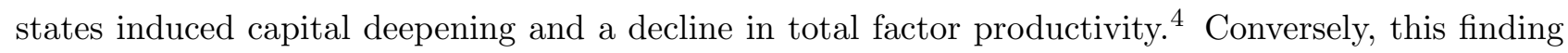
is in contrast with studies on European countries (Calcagnini et al., 2009; Cingano et al., 2010) who tend to find a negative relationship between EPL and, respectively, investment and capital-labor ratios. These differences may be reconciled adopting the view - proposed by Janiak and Wasmer (2013) - of a reverse U-shaped relationship between EPL and the capital-labor ratio. The present study plausibly focuses on the range of EPL where the relationship between EPL and capital-labor ratios is positive (very much as Autor et al., 2007, and Claessens and Ueda, 2008, who study the low-EPL U.S. labor market). The 1990 Italian reform, in fact, introduced EPL for firms which were previously exempted, mandating a marginal increase in the costs for unfair dismissals of permanent workers. Differently, the cross-country studies by Calcagnini et al. (2009) and Cingano et al. (2010) exploit variation in EPL across relatively highly regulated European countries, and thus arguably capture the decreasing

\footnotetext{
${ }^{3}$ Caggese and Cuñat (2008) analyze the impact of the joint presence of financial and labor markets imperfections on labour market outcomes and document that finance constrained Italian SMEs have more volatile employment and rely more heavily on temporary workers.

${ }^{4}$ This result is also consistent with Claessens and Ueda (2008) who find that the average impact of the adoption of wrongful-discharge protection norms in U.S. states on output growth was not significantly different from zero.
} 
side of the capital-EPL relationship.

Our estimates also indicate that the substitution between capital and labor did not happen across the board. It is more pronounced in firms with lower capital-labor ratios prior to the reform and, among those, in firm with higher liquid resources. This may be due to the fact that firms with little collateralizable assets have little access to the credit market and, therefore, they need to rely upon their own liquid resources to adjust the capital stock in response to the EPL reform. This result is consistent with Claessens and Ueda (2008) who find that the positive effect of EPL on output growth in knowledge-intensive industries is weaker in states with more stringent bank branches regulation, and with Cingano et al. (2010) and Calcagnini et al. (2009) who find that better functioning financial markets mitigate the negative effects of EPL on capital deepening and productivity.

Finally, we exploit the fact that firms enter the data set when granted a loan for the first time. Under the assumption that the reform does not differentially affect the composition of the pool of loan applicants above and below the threshold, this feature of the data allows us to estimate the impact of the reform on the probability to first access the credit market. Results indicate that the EPL reform reduces the probability that small firms obtain their first bank loan relative to larger firms, possibly due to the fact that the increase in EPL reduces both the value of the firm and the amount of internal resources that the firm can pledge as collateral against lenders.

The rest of the paper is organized as follows. Section 2 describes how firing restrictions evolved in Italy. Section 3 describes the data set and the sample selection rules. Section 4 explains the identification strategy used to evaluate the impact of EPL on capital deepening and productivity. Section 5 presents estimates of the impact of increased strictness of employment protection in small firms in Italy after 1990. Section 6 analyzes the role of financial markets imperfection and Section 7 concludes.

\section{The institutional background}

Over the years the Italian legislation ruling unfair dismissals has changed several times. Both the magnitude of the firing cost and the coverage of the firms subject to the restrictions have gone through extensive changes.

Individual dismissals were first regulated in Italy in 1966 through Law 604, which established that, in case of unfair dismissal, employers had the choice to either reinstate workers or pay severance, 
which depended on tenure and firm size. Severance pay for unfair dismissals ranged between 5 and 8 months for workers with less than two and a half years of tenure, between 5 and 12 months for those between two and a half and 20 years of tenure, and between 5 and 14 months for workers with more than 20 years of tenure in firms with more than 60 employees. Firms with fewer than 60 employees had to pay half the severance paid by firms with more than 60 employees, and firms with fewer than 35 workers were completely exempt.

In 1970, the Statuto dei Lavoratori (Law 300) established that all firms with more than 15 employees had to reinstate workers and pay their foregone wages in case of unfair dismissals. Firms with fewer than 15 employees remained exempt.5 The law prescribes that the 15 employees threshold should refer to establishments rather than to firms. In the data we only have information at the firm level. However, this is not likely to be a concern as in the empirical analysis we focus on firms between 10 and 20 employees that are plausibly single-plant firms.

Finally, Law 108 was introduced in July 1990 restricting dismissals for permanent contracts. In particular, this law introduced severance payments of between 2.5 and 6 months pay for unfair dismissals in firms with fewer than 15 employees. Firms with more than 15 employees still had to reinstate workers and pay foregone wages in case of unfair dismissals. This means that the cost of unfair dismissals for firms with fewer than 15 employees increased relative to the cost for firms with more than 15 employees after 1990.

For our purposes, this reform has two attractive features. First, it was largely unexpected: the first published news of the intention to change the EPL rules for small firms appeared in the main Italian financial newspaper Il Sole 24 Ore at the end of January 1990. Second, it imposed substantial costs on small firms: Kugler and Pica (2008) look at the effect of this reform on job and workers flows and find that accessions and separations decreased by about $13 \%$ and $15 \%$ in small relative to large firms after the reform.

\section{$3 \quad$ Data description and sample selection rules}

Data for firms are obtained from the Company Accounts Data Service (Centrale dei Bilanci, or CB for brevity). The data provide detailed information on a large number of balance-sheet items since

\footnotetext{
${ }^{5}$ See Boeri and Jimeno (2003) for a theoretical explanation of why these exemptions may be in place. In this paper we focus only on individual dismissals. An equivalent threshold applies in Italy for collective dismissals, i.e. dismissals of more than five employees within 120 days. Leonardi and Pica (2013) show that the reform on collective dismissals does no interfere with the results on the individual dismissal reform under consideration.
} 
the early 1980s together with a full description of firm characteristics (as location, year of foundation, sector, ownership structure), plus other variables of economic interest usually not included in balance sheets, such as employment and flow of funds. Company accounts are collected for approximately 30,000 firms per year by the Service, which was established jointly by the Bank of Italy, the Italian Banking Association and a pool of leading banks to gather and share information on borrowers. Since banks rely heavily on these data when granting and pricing loans, they are subject to extensive quality controls by a pool of professionals.

Firms enter the data set when first granted a loan (a feature that we will later exploit to estimate the impact of the reform on access to credit) ${ }_{5}^{6}$ While accounting for a very large fraction of manufacturing employment and value added, the focus on the level of borrowing skews the sample towards larger firms. Moreover, the employment figure are not always reported accurately, as this piece of information is not a mandatory balance sheet item. To address both issues we integrated the CB data set with information recovered from the firms' file of the National Social Security (INPS) Archives. This administrative source covers the universe of private non agricultural firms, and contains accurate figures on their annual employment, an explicit requirement for firms when paying social security contributions. Merging these data with CB therefore allows us to improve on the initial information on firm-level employment; as they cover the universe of firms, the INPS data also allow computing post-stratification weights that can be used to re-balance the firm size distribution 7 In section 5 we present results with and without weights, which do not differ significantly. This is because within the narrow size window we focus on (10-20 employees) CB representativeness is fairly homogeneous, as inspection of the weights indicates.

Figure 1 visualizes the skewness of the size distribution towards big firms. Importantly, the same figure also shows no dip in the size distribution at 16 employees, neither before nor after the reform, an issue we will analyze further in Appendix $\mathrm{A}^{8}$

Standard treatment of the data lead us to our final variables and sample. We rely on CB for data on value added and investment and on INPS data for employment-related variables. Firm-level capital

\footnotetext{
${ }^{6}$ More specifically, banks associated with the Centrale dei Bilanci agreed to include in the data set those clients from the Credit Register (a database of both individuals and firms who have been approved of for a loan) who have actually used the loan. Hence, CB firms are a subset of those included in the Credit Register.

${ }^{7}$ For each cell $i=1 . . I$ the weights are constructed as follows:

$$
\text { weight }_{i}=\left(\# \text { firms }_{i} / \# \text { firms }\right)_{I N P S} /\left(\# \text { firms }_{i} / \# \text { firms }\right)_{C E B I L}
$$

We experimented re-balancing both for size only and for multiple characteristics (size, industry and geographical location).

${ }^{8}$ Also Leonardi and Pica (2013), using administrative data, find no effect of the 1990 reform on firm size distribution in Italy. In a similar vein, Bauer et al. (2007) find no effect of EPL reform for firms at 10 employees in Germany.
} 


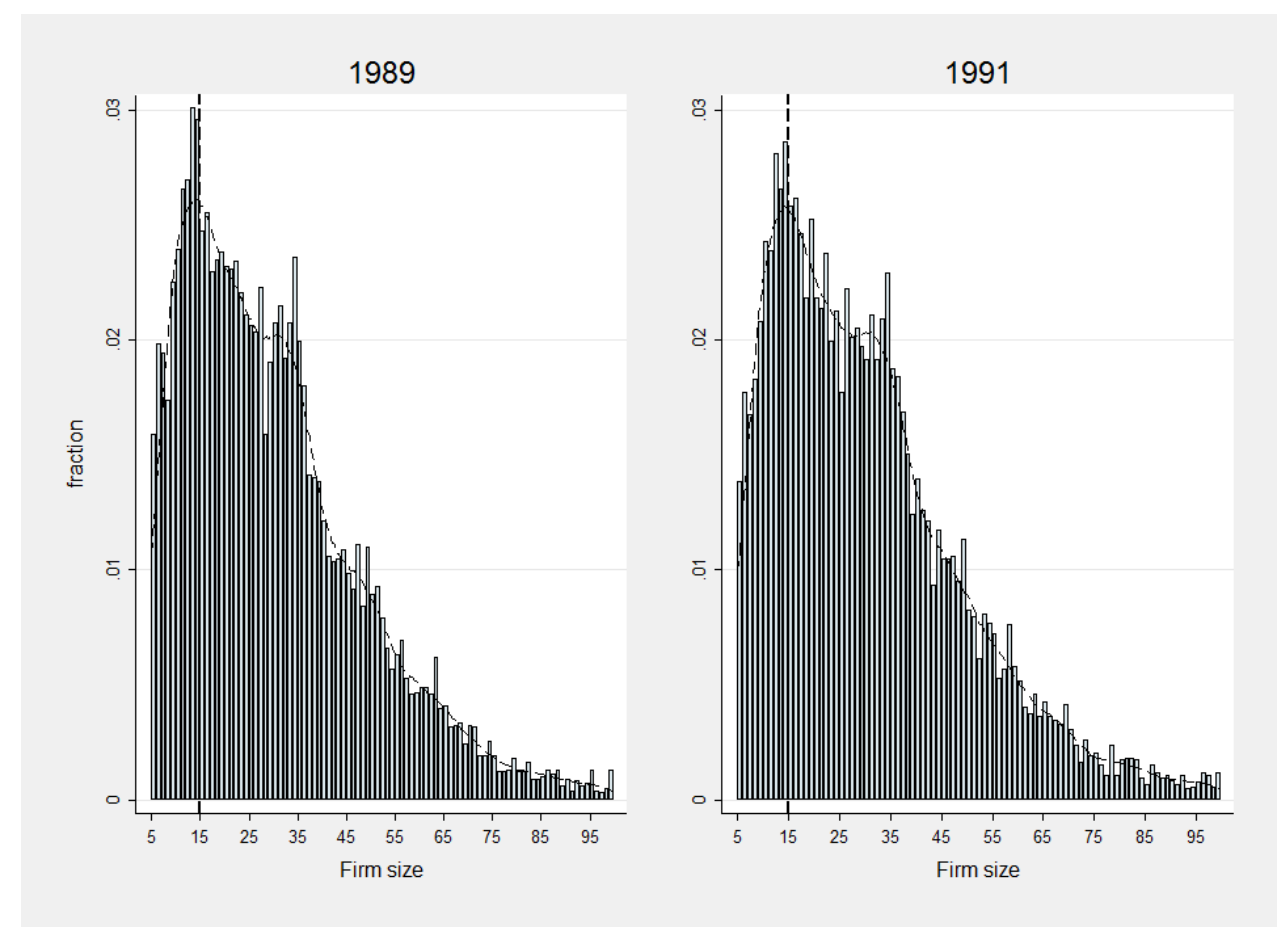

FigURE 1. Frequency of firm size in 1989 and 1991

stocks are constructed applying the perpetual inventory method, using industry-specific deflators and depreciation rates and book capital as a proxy for the capital stock in the first year. Total Factor Productivity is obtained applying the multi-step estimation algorithm devised by Olley and Pakes (1996) 9 We delete as outliers 2246 out of 99391 initial firm-year observations whose capital-output ratio is two inter-quartile ranges away from the median. With regards to the sample period, we restrict the sample around the reform years (1986-1994), and remove year 1990 because the reform occurred in the month of July. To preserve comparability between treatment and control groups, we further restrict the sample to firms within the interval 10-20 employees, yielding a sample size of slightly more than 20000 observations (6656 firms). In Section 5.1, Table 6 tests the robustness of our results both to different time periods and to the inclusion of 1990; Table 7 shows that the results are invariant to different size ranges.

Tables 1 and 2 show descriptive statistics.

\footnotetext{
${ }^{9}$ The procedure allows for direct estimates of production coefficients, accounting for both endogeneity in the choice of inputs (by approximating unobserved productivity shocks with a nonparametric function of observable variables) and for selection in firms continuation decision (introducing a Heckman-type correction term).
} 
TABLE 1. Descriptive statistics

\begin{tabular}{lcccccc}
\hline \hline & $(1)$ & $(2)$ & $(3)$ & $(4)$ & $(5)$ & $(6)$ \\
\hline & Mean & $\begin{array}{c}\text { Standard } \\
\text { deviation }\end{array}$ & \multicolumn{3}{c}{ Percentiles } & \multirow{2}{*}{ N } \\
\cline { 5 - 6 } & & & & 50 & 90 & \\
Employment & 14.962 & 3.104 & 11 & 15 & 19 & 20235 \\
Log capital & 6.603 & 0.922 & 5.342 & 6.670 & 7.735 & 20235 \\
Log (capital/value added) & 0.273 & 0.806 & -0.853 & 0.340 & 1.279 & 20235 \\
Log value added & 6.330 & 0.526 & 5.702 & 6.327 & 6.974 & 20235 \\
Fraction of white collars & 0.299 & 0.222 & 0.083 & 0.235 & 0.600 & 19943 \\
TFP & 2.316 & 0.519 & 1.646 & 2.341 & 2.951 & 20235 \\
Job reallocation & 0.139 & 0.269 & 0.000 & 0.074 & 0.267 & 16145 \\
Entry in the dataset & 0.103 & 0.304 & 0.000 & 0.000 & 1.000 & 20230 \\
Cash-flow / Fixed Assets & 0.182 & 0.217 & 0.039 & 0.131 & 0.389 & 17055 \\
\hline \hline
\end{tabular}

Notes: Job reallocation is the Absolute Value of Labour Reallocation calculated as $\frac{2\left(e_{j t}-e_{j t-1}\right)}{e_{j t}+e_{j t-1}}$; Total Factor Productivity is obtained applying the multi-step estimation algorithm devised by Olley and Pakes (1996). Entry in the dataset is a dummy that indicates the year of the first appearance of the firm in the dataset. The ratio Cash-flow / Fixed Assets is measured in the pre-reform period.

TABle 2. Descriptive statistics by treatment and control before and after the reform

\begin{tabular}{lcccc}
\hline \hline & $(1)$ & $(2)$ & $(3)$ & $(4)$ \\
\hline & \multicolumn{2}{c}{ Pre-reform } & \multicolumn{2}{c}{ Post-reform } \\
& Small firms & Large firms & Small firms & Large firms \\
& & & & \\
Employment & 12.591 & 17.983 & 12.588 & 17.983 \\
& $(1.664)$ & $(1.418)$ & $(1.692)$ & $(1.424)$ \\
Log capital & 6.402 & 6.773 & 6.491 & 6.823 \\
& $(0.958)$ & $(0.849)$ & $(0.916)$ & $(0.878)$ \\
Log (capital/value added) & 0.298 & 0.364 & 0.225 & 0.228 \\
& $(0.827)$ & $(0.747)$ & $(0.837)$ & $(0.784)$ \\
Log value added & 6.104 & 6.410 & 6.266 & 6.595 \\
& $(0.510)$ & $(0.470)$ & $(0.512)$ & $(0.475)$ \\
Fraction of white collars & 0.299 & 0.269 & 0.320 & 0.297 \\
& $(0.232)$ & $(0.198)$ & $(0.235)$ & $(0.212)$ \\
TFP & 2.258 & 2.218 & 2.384 & 2.379 \\
Job reallocation & $(0.519)$ & $(0.499)$ & $(0.532)$ & $(0.500)$ \\
& 0.169 & 0.153 & 0.131 & 0.118 \\
Entry in the dataset & $(0.320)$ & $(0.319)$ & $(0.237)$ & $(0.224)$ \\
& 0.158 & 0.112 & 0.074 & 0.071 \\
Cash-flow / Fixed Assets & $(0.365)$ & $(0.315)$ & $(0.262)$ & $(0.256)$ \\
& 0.181 & 0.164 & 0.197 & 0.189 \\
& $(0.237)$ & $(0.196)$ & $(0.218)$ & $(0.210)$ \\
\hline \hline
\end{tabular}

Notes: Job reallocation is the Absolute Value of Labour Reallocation calculated as $\frac{2\left(e_{j t}-e_{j t-1}\right)}{e_{j t}+e_{j t-1}}$; Total Factor Productivity is obtained applying the multi-step estimation algorithm devised by Olley and Pakes (1996). Entry in the dataset is a dummy that indicates the year of the first appearance of the firm in the dataset. The ratio Cash-flow / Fixed Assets is measured in the pre-reform period. Standard deviations in parentheses. 


\section{Identification strategy and regression model}

There are several margins of adjustment to an EPL reform which raises the price of labor by making it more expensive to hire and fire. Firms may substitute towards other inputs such as capital; furthermore, given the restrictions on firms' ability to adjust, we also may expect TFP to be reduced. Finally the adoption of dismissal protections may generate compositional shifts in the labor force.

Therefore, our estimand of interest is the average treatment effect of EPL on capital, value added, TFP, the share of white collar workers and, of course, job flows. We exploit both the discontinuity in EPL at the 15 employees threshold and the reform of EPL which affected only small firms to build an RDD combined with a DID strategy to estimate the causal effect of EPL on various outcomes.

We compare the change in the dependent variable - say capital - just below 15 employees before and after the 1990 reform to the change in the same variable among firms just above 15 employees. The assumption requires to interpret the effect of EPL on capital as causal is that any variable that affects capital is either continuous at the threshold (as in standard RDD) or its discontinuity is constant over time (as in standard DID). Another identification assumption is that capital in firms marginally below the 15 employees threshold (10-15) is expected to diverge from capital in firms just above the threshold (16-20) for no other reason than the law change, i.e. the capital trend in firms above 15 employees represents a good counterfactual for the capital trend in firms with 15 or fewer employees, a reasonable assumption in the neighborhood of the threshold. We, thus, estimate the following model:

$$
\begin{aligned}
x_{j t} & =\beta^{\prime} X_{j t}+\delta_{1} D_{j t}^{S}+\delta_{2}\left(D_{j t}^{S} \times \text { Post }\right)+v_{j}+u_{j t} \\
D_{j t}^{S} & =1[\text { firm size } \leq 15 \text { in year } t] \\
\text { Post } & =1[\text { year } \geq 1991]
\end{aligned}
$$

The dependent variable is the variable $x$ at firm $j$ in year $t$ which is the log capital stock, log capital/value added, log value added, log fraction of white collars, TFP and the Davis-Haltiwanger index of job flows.

The variable Post is a dummy that takes the value of 1 after 1991 and zero otherwise (its main effect is not included because it is absorbed by the year dummies, see below); $D_{j t}^{S}$ is a dummy that takes the value of 1 if the firm is small in year $t$ and 0 if the firm is big. The interaction term $D_{j t}^{S} \times$ Post between the small firm dummy and the post-reform dummy is included to capture the effect of the 


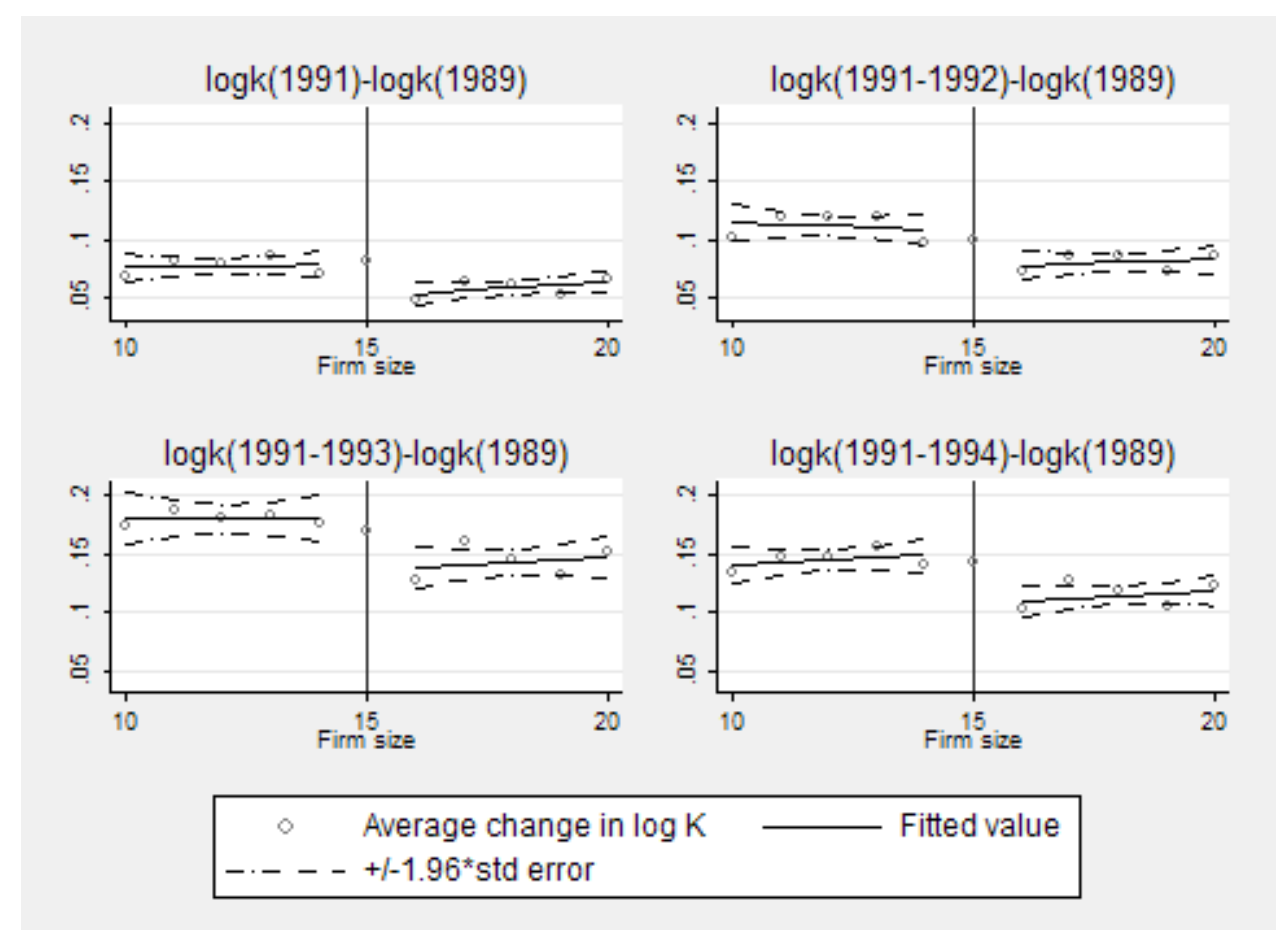

FIGURE 2. The dots are the observed differences between the post-reform log capital stock (averaged over the years indicated in parenthesis) minus the pre-reform log capital stock of year 1989. The solid line is a fitted regression of log capital differences on firm size, performed separately on either side of the threshold.

EPL reform on the variable of interest 10

The matrix $X_{j t}$ contains a polynomial of third degree in firm size. Notice that since identification comes from firm size as measured by the number of employees, we cannot use dependent variables in per-worker terms. Nevertheless, given that we control for firm size with a flexible third degree polynomial, all effects are to be read holding labor constant. Therefore, a positive impact on the log capital stock implies capital deepening. We also include, in all specifications, year and industry-year effects to reduce the sampling variability of the estimates. The term $v_{j}$ captures any unobserved firmspecific time-invariant characteristics that may affect the outcome variable and be - at the same time - correlated with the treatment status, thus biasing the results. Finally, we cluster standard errors at the firm level (Bertrand et al., 2004) to allow for time-series persistence of the shocks.

We illustrate the strategy to identify the impact of the change in dismissal costs in Figure 2 where we plot the difference in $\log (K)$ against firm size. The mean of the dependent variables is estimated

\footnotetext{
${ }^{10}$ Other papers have exploited the discontinuities in firing costs regimes that apply to firms of different sizes within countries. Boeri and Jimeno (2005) assess the effect of EPL on lay-off probabilities by comparing firms below and above 15 employees in Italy. Kugler and Pica (2006) examine the joint impact of EPL and product market regulation on job flows in Italy using both the firm size threshold and a law change. Using a difference-in-differences approach, Bauer et al. (2007) investigate the impact of granting employees the right to claim unfair dismissal on employment in small German firms. Leonardi and Pica (2013) look at the effects on wages.
} 
non parametrically separately for each side of the threshold. Firms below the 15 employees threshold show a higher capital stock than neighboring firms, after the reform. We explore formally the effect of EPL on these dependent variables in the regressions below.

\subsection{Quantile regression model}

Theory suggests that the reform should have a larger impact on firms with lower capital-labor ratios because labor-abundant firms should be hit relatively harder by the reform. To investigate the hypothesis that firms with low capital-labor ratios react more to the reform, we run a quantile regression at different points of the distribution using as a dependent variable $\log$ capital. Let $Q_{\theta}\left(\log \left(k_{j t}\right) \mid X_{j t}\right)$ for $\theta \in(0,1)$ denote the $\theta^{\text {th }}$ quantile of the distribution of $\log \left(k_{j t}\right)$ conditional on firm characteristics included in the matrix $X_{j t}$ (same controls as in Equation (1)). The model of the conditional quantile is:

$$
Q_{\theta}\left(\log \left(k_{j t}\right) \mid X_{j t}\right)=\beta_{\theta}^{\prime} X_{j t}+\delta_{1 \theta} D_{j t}^{S}+\delta_{2 \theta}\left(D_{j t}^{S} \times \text { Post }\right)+v_{j}
$$

Notice that equation (2) also includes firm fixed effects. The estimation of a quantile model with fixed effects is not trivial, because its intrinsic non-linearity implies that standard demeaning techniques are not feasible. We follow the approach of Canay (2011) who introduces a simple two-step estimator, which is consistent and asymptotically normal when both the number of firms $(N)$ and the number of period $(T)$ approach infinity ${ }^{11}$ under the assumption that the firm fixed effects are pure location shifters, i.e. they affect all quantiles in the same way. Inference is based on bootstrapped standard errors obtained from individual resampling. Identification of equation 1 and equation 2 is based on the assumption of the absence of sorting in or out of the treatment status around the time of the reform. The inclusion of firms fixed effects in the regressions controls for time-invariant unobservable characteristics that may be correlated with treatment status. However in principle selfselection may take place according to time-varying unobservable firms' characteristics. In Appendix A we show some results to convince the reader that there is no evidence of significant sorting behaviour of firms.

\footnotetext{
${ }^{11}$ Using Monte-carlo simulations Canay (2011) shows that already with $T=10$, the bias is fairly low irrespective of the value of $N$.
} 
TABLE 3. Firm Fixed Effects

\begin{tabular}{lcccccc}
\hline \hline \multirow{2}{*}{ VARIABLES } & $\begin{array}{c}(1) \\
\log (\text { Capital })\end{array}$ & $\begin{array}{c}(2) \\
\log (\text { Capital }) \\
\text { Value added })\end{array}$ & $\begin{array}{c}(3) \\
\log (\text { Value } \\
\text { added })\end{array}$ & $\begin{array}{c}(4) \\
\text { Fraction of } \\
\text { white collars }\end{array}$ & $\begin{array}{c}(5) \\
\text { TFP }\end{array}$ & $\begin{array}{c}(6) \\
\text { Job } \\
\text { reallocation }\end{array}$ \\
\hline \multirow{3}{*}{ Small firm $\times$ Post 1990 } & $0.047^{* * *}$ & $0.059^{* * *}$ & -0.013 & -0.002 & $-0.029^{*}$ & 0.010 \\
& $(0.012)$ & $(0.015)$ & $(0.011)$ & $(0.003)$ & $(0.011)$ & $(0.012)$ \\
Small firm & $-0.045^{* * *}$ & $-0.077^{* * *}$ & $0.032^{*}$ & 0.005 & $0.055^{* * *}$ & -0.015 \\
& $(0.013)$ & $(0.017)$ & $(0.013)$ & $(0.003)$ & $(0.014)$ & $(0.014)$ \\
Observations & & & & & & \\
R-squared & 20,235 & 20,235 & 20,235 & 19,943 & 20,235 & 16,145 \\
\hline \hline
\end{tabular}

Notes: Robust standard errors clustered by firm in parentheses. All specifications include a third degree polynomial in the size of the firm, firm fixed effects, and sector-year dummies. One asterisk denotes significance at 5\%; two asterisks denote significance at 1\%; three asterisks denotes significance at $0.1 \%$.

\section{The effects of the 1990 reform}

Table 3 reports the coefficients and standard errors of equation 1 . We focus on the following firm-level outcomes: (log of) Capital Stock, Capital-Value Added Ratio, Value Added, TFP, Fraction of White Collars and the Absolute Value of Labour Reallocation calculated as $\frac{2\left(e_{j t}-e_{j t-1}\right)}{e_{j t}+e_{j t-1}}$. The effect of interest is captured by the interaction $\left(D_{j t}^{S} \times\right.$ Post $)$. All specifications include a third degree polynomial in firm size, local labor market dummies, year, industry and industry-year effects. The reported standard errors account for within-firm correlation.

Our main interest is focused on the effect of EPL on log capital stock. Since we control for a polynomial in firm size on the right hand side, all effects are to be read holding labor constant (capital deepening).

We find a positive and significant effect on the capital stock and capital-value added ratio. We also find a three percent negative effect on total factor productivity.

Results suggests that the introduction of EPL causes capital deepening and a weakly significant decline in TFP. The former result does not seem to derive from small firms mechanically converging to large firms. Figure 3 shows that the pre-reform trends of log capital are reasonably parallel. Additionally, were this result mechanical, it should pop up also in years different from the reform year. Table 8 in Section 5.1 shows instead that the effect vanishes when considering 1988 and 1992 as fake reform years.

The results on capital deepening and TFP are consistent with models where inefficient dismissal 


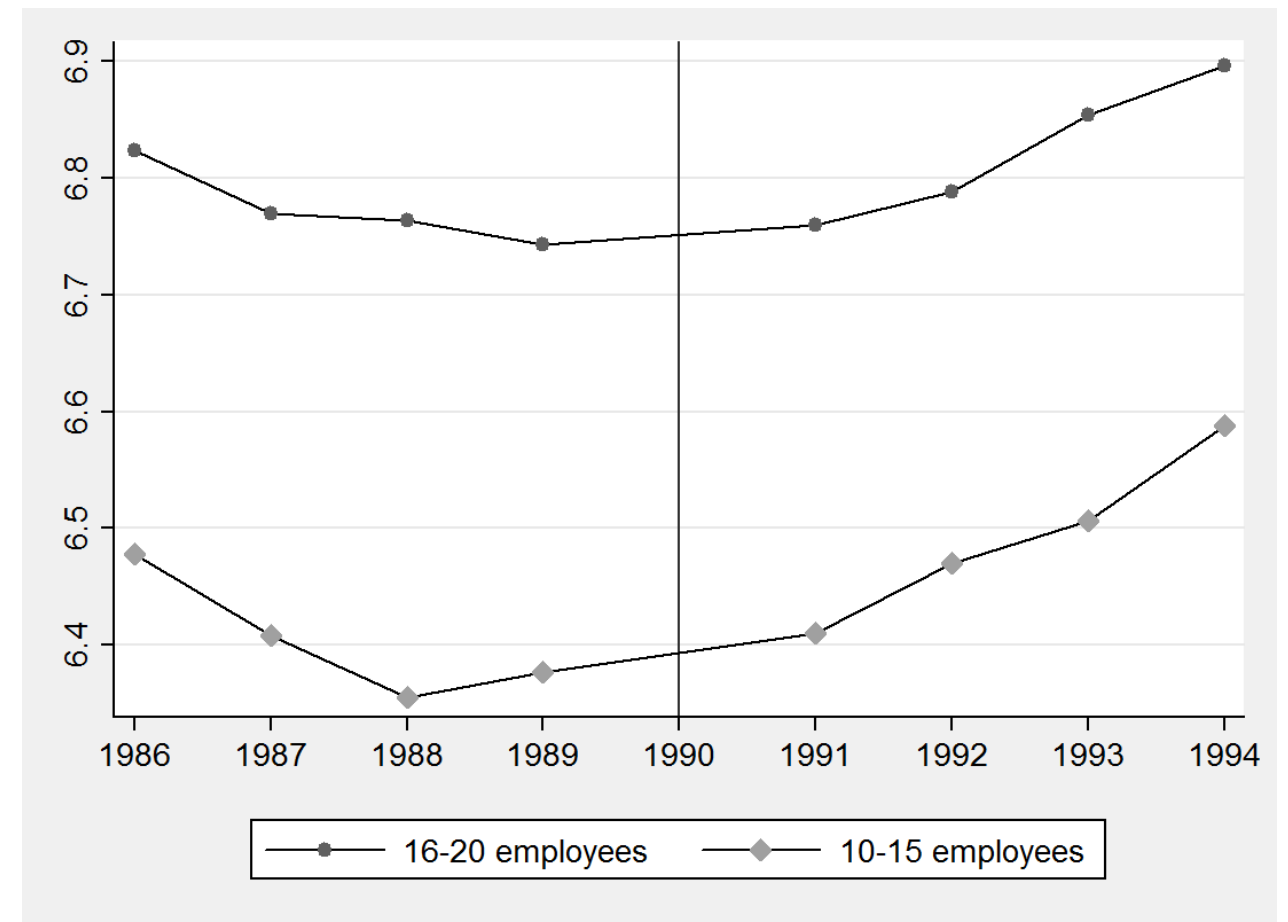

FigURE 3. Evolution of log capital

protection unambiguously reduces allocative efficiency and provides firms with an incentive to substitute from labor to other factors of production. The implications for productivity are, in theory, less clear cut. If dismissal protection causes firms to retain (some) unproductive workers, this will cause a decline in (labor) productivity, ceteris paribus. Offsetting this factor, firms may screen new hires more stringently, leading to a favorable compositional shift in the productivity of the employed workforce. Moreover, capital deepening may also raise the marginal product of labor. Hence, from a theoretical standpoint the net impact on technical efficiency (as opposed to allocative efficiency) is ambiguous. Overall, our empirical results on TFP suggest that the net effect is negative.

Column 6 shows no significant effect on job flows, a finding that might be driven by measurement issues, that is, the use of annual as opposed to shorter-frequency data. Previous studies looking at annual rates of job reallocation also found that EPL has little effect on job flows (see Blanchard and Portugal, 2001; Bertola and Rogerson, 1997; and Martins, 2009). Contrasting results obtained using quarterly and yearly rates of reallocation, Blanchard and Portugal (2001) conjecture that employment protection only impairs high-frequency flows.

We next investigate the hypothesis that firms with low capital-labor ratios react more to the reform. Table 4, Panel A, shows results from a quantile regression at different points of the distribution using as a dependent variable log capital. The estimates indicate that the effect of the reform on capital 
TABLE 4. Effect of the reform at different quantiles of the log capital distribution

\begin{tabular}{|c|c|c|c|c|c|}
\hline & $(1)$ & 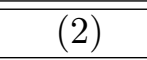 & (3) & 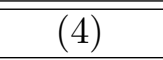 & 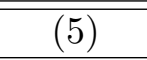 \\
\hline & \multicolumn{5}{|c|}{ Quantile regressions } \\
\hline & 10 & 25 & 50 & 75 & 90 \\
\hline \multicolumn{6}{|l|}{ Panel A: capital stock } \\
\hline Small firm $\times$ Post 1990 & $\begin{array}{c}0.087^{* * *} \\
(0.015)\end{array}$ & $\begin{array}{c}0.030^{* * *} \\
(0.007)\end{array}$ & $\begin{array}{c}0.037^{* * *} \\
(0.004)\end{array}$ & $\begin{array}{c}0.022^{* *} \\
(0.007)\end{array}$ & $\begin{array}{c}0.016 \\
(0.013)\end{array}$ \\
\hline Observations & 20,235 & 20,235 & 20,235 & 20,235 & 20,235 \\
\hline \multicolumn{6}{|c|}{ Panel B: capital-output ratio } \\
\hline Small firm $\times$ Post 1990 & $\begin{array}{c}0.079^{* * *} \\
(0.016)\end{array}$ & $\begin{array}{c}0.050^{* * *} \\
(0.008)\end{array}$ & $\begin{array}{c}0.059^{* * *} \\
(0.001)\end{array}$ & $\begin{array}{c}0.054^{* * *} \\
(0.010)\end{array}$ & $\begin{array}{c}0.044^{* * *} \\
(0.016)\end{array}$ \\
\hline Observations & 20,235 & 20,235 & 20,235 & 20,235 & 20,235 \\
\hline \multicolumn{6}{|l|}{ Panel C: productivity } \\
\hline Small firm $\times$ Post 1990 & $\begin{array}{c}-0.040^{* * *} \\
(0.012)\end{array}$ & $\begin{array}{l}-0.017^{*} \\
(0.008)\end{array}$ & $\begin{array}{c}-0.029^{* * *} \\
(0.000)\end{array}$ & $\begin{array}{c}-0.033^{* * *} \\
(0.007)\end{array}$ & $\begin{array}{c}-0.030^{*} \\
(0.012)\end{array}$ \\
\hline Observations & 20,235 & 20,235 & 20,235 & 20,235 & 20,235 \\
\hline
\end{tabular}

Notes: Bootstrapped standard errors clustered by firm in parentheses (100 replications). All specifications include a third degree polynomial in the size of the firm, firm fixed effects, and sector-year dummies. One asterisk denotes significance at 5\%; two asterisks denote significance at $1 \%$; three asterisks denotes significance at $0.1 \%$

is highest at the $10^{\text {th }}$ percentile and decreases along the capital distribution reaching non significance at the $90^{t h}$ percentile. A similar, slightly more nuanced, decreasing pattern shows up also for the capital-output ratio in Panel B, in line with the idea that firms with a high share of labor costs were hit harder by the reform. Finally, not unexpectedly, there is no clear pattern in the impact of the reform along the distribution of TFP (Panel C).

The literature on EPL typically looks at the effect of the extensive margin of firm entry. However, differently from other data sources, firms appear in our data set when they first obtain a bank loan (as explained in Section 3). Therefore, entry in the data set can be used as a proxy for first access to credit.

Unfortunately, we do not observe the entire pool of loan applicants, therefore in order to estimate the effect of EPL on the probability to first access bank credit, we need to rely on the assumption that the size and composition of the pool of applicants is not changing differentially over time above and below the 15 employee threshold. Under this assumption, Table 5 shows that small firms are $4 \%$ points 
TABLE 5. Impact of the reform on the first access to bank loans

\begin{tabular}{lccccc}
\hline \hline & $(1)$ & $(2)$ & $(3)$ & $(4)$ & $(5)$ \\
& Probit & $\begin{array}{c}\text { Probit } \\
\text { Random effects }\end{array}$ & \multicolumn{3}{c}{$\begin{array}{c}\text { Linear } \\
\text { Probability Model }\end{array}$} \\
\cline { 4 - 6 } Small firm $\times$ Post 90 & & & & & \\
& $-0.214^{* * *}$ & $-0.260^{* * *}$ & $-0.044^{* * *}$ & $-0.044^{* * *}$ & $-0.049^{* * *}$ \\
Small firm & $(0.051)$ & $(0.058)$ & $(0.009)$ & $(0.008)$ & $(0.011)$ \\
& $0.149^{*}$ & $0.175^{*}$ & $0.038^{* *}$ & $0.035^{*}$ & $0.033^{*}$ \\
& $(0.072)$ & $(0.080)$ & $(0.013)$ & $(0.0133)$ & $(0.014)$ \\
Observations & & & & & \\
R-squared & 20,071 & 20,230 & 20,230 & 20,230 & 20,230 \\
& & & 0.038 & 0.038 & 0.120 \\
Local labor market effects & YES & YES & NO & YES & NO \\
Firm fixed effects & NO & NO & NO & NO & YES \\
\hline \hline
\end{tabular}

Notes: Robust standard errors clustered by firm in parentheses in column 1. All specifications include a third degree polynomial in the size of the firm and sector-year dummies. Columns (1) and (2) show coefficients from Probit estimates. One asterisk denotes significance at 5\%; two asterisks denote significance at $1 \%$; three asterisks denotes significance at $0.1 \%$.

less likely to obtain their first bank loans after the reform. The Table reports similar results across different specifications. The Probit results in columns 1 and 2 are in line with the linear probability models as, for example, the marginal effect implied in column (1) by the -0.214 coefficient is, again, equal to -0.04 with a 0.01 standard error.

These results may be due to the fact that the increase in EPL reduces both the value of the firm and the amount of internal resources that the firm can pledge as collateral against the bank to obtain a loan. Under the assumption that the reform did not change significantly firm creation below and above the threshold ${ }^{12}$ this evidence suggests that the reform affects treated firms also through changes in the availability of credit. Thus, while any firm-specific time-invariant characteristics that affect firms' access to credit are controlled for by firm fixed effect, our analysis should be read as capturing the overall effect of the 1990 EPL reform also via changes in the possibility to obtain bank loans.

\subsection{Robustness checks}

For brevity, our robustness checks focus on our main variable of interest, log capital. First, we relax the time period (Table 6) and the size range (Table 7) of the analysis. The results are qualitatively

\footnotetext{
${ }^{12}$ The available evidence in this respect is mixed and depends on the variables used. Kugler and Pica (2008) using the date of incorporation of the firm as an indicator of firm entry find a negative significant effect of the reform on firm entry on a nationwide Italian sample representative of the population of workers. Leonardi and Pica (2013) using firm appearance in the sample (which corresponds to appearance of the firm in the economy given that the sample is the universe of firms in two Italian provinces) find no effect on entry.
} 
TABLE 6. Robustness to different time periods: dependent variable $\log \left(k_{j t}\right)$

\begin{tabular}{lccccccc}
\hline \hline \multirow{2}{*}{ Time period } & $(1)$ & $(2)$ & $(3)$ & $(4)$ & $(5)$ & $(6)$ & $(7)$ \\
& $1986-94$ & $1987-92$ & $1988-92$ & $1989-93$ & $1988-93$ & $1987-94$ & $1988-94$ \\
\hline \multirow{2}{*}{ Small firm $\times$ Post 1990} & $0.047^{* * *}$ & $0.041^{* * *}$ & $0.041^{* * *}$ & $0.046^{* * *}$ & $0.043^{* * *}$ & $0.043^{* * *}$ & $0.047^{* * *}$ \\
\multirow{3}{*}{ Small firm } & $(0.012)$ & $(0.012)$ & $(0.012)$ & $(0.013)$ & $(0.013)$ & $(0.012)$ & $(0.013)$ \\
& $-0.045^{* * *}$ & $-0.045^{* *}$ & $-0.049^{* *}$ & $-0.048^{* *}$ & $-0.045^{* *}$ & $-0.043^{* *}$ & $-0.048^{* *}$ \\
& $(0.013)$ & $(0.015)$ & $(0.017)$ & $(0.018)$ & $(0.016)$ & $(0.014)$ & $(0.016)$ \\
Observations & & & & & & & \\
R-squared & 20,235 & 12,855 & 10,608 & 10,952 & 13,243 & 18,069 & 15,822 \\
\hline \hline
\end{tabular}

Notes: Robust standard errors clustered by firm in parentheses. The first column includes 1990. All specifications include a third degree polynomial in the size of the firm, firm fixed effects, and sectoryear dummies. One asterisk denotes significance at $5 \%$; two asterisks denote significance at $1 \%$; three asterisks denotes significance at $0.1 \%$.

similar to those in Table 3, confirming the positive effect of the reform on capital intensity. In Table 8 we implement placebo tests by estimating the treatment effect at fake firm size thresholds and fake reform years, where there should be no effect. We estimate the treatment effect below and above the fake 12 and 18 employees thresholds. In Columns 1 and 2 we estimate the treatment effect before and after the fake reform years 1988 and 1992 (excluding in turn the fake year of the reform as we did with 1990 in Table 3). The interaction between the small firm and the post-reform dummy is not significant. This implies that the effect on capital is not a mechanical a convergence effect, due to firms with less capital accumulating it faster. Columns 3 and 4 show that the fake firm size threshold is still positive and slightly significant when considering the 12-employee threshold, but it is no longer significant at 18 employees.

Finally, Table 9 shows results from weighted regressions to account for the possibility that the Company Accounts Data Service undersamples small firms, which are more likely to be financially constrained and less likely to show up in the data set. Regression weights by firm size are given by the ratio between the total number of firms in the economy (from Social Security Records) and the number of firms in the Company Accounts Data Service. Results are qualitatively similar to those shown in Table 3 suggesting that the undersampling of smaller firms is not a major issue within our narrow 10-20 firm-size window. 
TABLE 7. Robustness to different size ranges: dependent variable $\log \left(k_{j t}\right)$

\begin{tabular}{lccccc}
\hline \hline \multirow{2}{*}{ Size range } & $(1)$ & $(2)$ & $(3)$ & $(4)$ & $(5)$ \\
& $5-20$ & $5-30$ & $5-25$ & $10-25$ & $10-35$ \\
Small firm $\times$ Post 1990 & $0.049^{* * *}$ & $0.052^{* * *}$ & $0.054^{* * *}$ & $0.051^{* * *}$ & $0.043^{* * *}$ \\
& $(0.012)$ & $(0.010)$ & $(0.011)$ & $(0.012)$ & $(0.011)$ \\
Small firm & $-0.040^{* * *}$ & $-0.040^{* * *}$ & $-0.043^{* * *}$ & $-0.040^{* * *}$ & $-0.038^{* * *}$ \\
& $(0.012)$ & $(0.011)$ & $(0.011)$ & $(0.011)$ & $(0.011)$ \\
Observations & & & & & \\
R-squared & 26,477 & 42,541 & 34,663 & 28,421 & 44,403 \\
\hline \hline
\end{tabular}

Notes: Robust standard errors clustered by firm in parentheses. All specifications include a third degree polynomial in the size of the firm, firm fixed effects, and sector-year dummies. One asterisk denotes significance at 10\%; two asterisks denote significance at 5\%; three asterisks denotes significance at $1 \%$.

TABLE 8. Falsification: fake firm size threshold and fake reform years. Dependent variable $\log \left(k_{j t}\right)$

\begin{tabular}{|c|c|c|c|c|}
\hline & (1) & 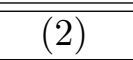 & 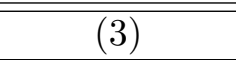 & $\overline{(4)}$ \\
\hline & \multicolumn{2}{|c|}{ Fake reform year } & \multicolumn{2}{|c|}{ Fake firm size threshold } \\
\hline & 1988 & 1992 & 12 employees & 18 employees \\
\hline Small firm $\times$ post 1988 & $\begin{array}{l}-0.012 \\
(0.011)\end{array}$ & & & \\
\hline Small firm $\times$ post 1992 & & $\begin{array}{c}0.025 \\
0.014)\end{array}$ & & \\
\hline Small firm $12 \times$ post 1990 & & & $\begin{array}{l}0.034^{*} \\
(0.017)\end{array}$ & \\
\hline Small firm $18 \times$ post 1990 & & & & $\begin{array}{c}0.016 \\
(0.014)\end{array}$ \\
\hline Observations & 20,764 & 20,291 & 20,235 & 20,235 \\
\hline R-squared & 0.155 & 0.163 & 0.154 & 0.162 \\
\hline
\end{tabular}

Notes: Robust standard errors clustered by firm in parentheses. All specifications include a third degree polynomial in the size of the firm, firm fixed effects, and sector-year dummies. One asterisk denotes significance at 5\%; two asterisks denote significance at 1\%; three asterisks denotes significance at $0.1 \%$. 
TABLE 9. Weighted Regressions

\begin{tabular}{lcccccc}
\hline \hline VARIABLES & $\begin{array}{c}(1) \\
\text { Log(Capital) }\end{array}$ & $\begin{array}{c}\text { Log(Capital } \\
\text { Value added) }\end{array}$ & $\begin{array}{c}\text { Log(Value } \\
\text { added) }\end{array}$ & $\begin{array}{c}(4) \\
\text { Fraction of } \\
\text { white collars }\end{array}$ & $\begin{array}{c}(5) \\
\text { TFP }\end{array}$ & $\begin{array}{c}\text { Job } \\
\text { reallocation }\end{array}$ \\
\hline \multirow{2}{*}{ Small firm $\times$ Post 1990 } & $0.042^{* *}$ & $0.060^{* *}$ & -0.018 & -0.003 & $-0.035^{*}$ & 0.007 \\
Small firm & $(0.016)$ & $(0.019)$ & $(0.014)$ & $(0.004)$ & $(0.015)$ & $(0.015)$ \\
& 0.030 & -0.024 & $0.054^{*}$ & $0.014^{*}$ & 0.032 & -0.046 \\
Observations & $(0.029)$ & $(0.034)$ & $(0.027)$ & $(0.006)$ & $(0.027)$ & $(0.030)$ \\
\hline \hline
\end{tabular}

Notes: Robust standard errors clustered by firm in parentheses. All specifications include a third degree polynomial in the size of the firm, firm fixed effects, and sector-year dummies. Regression weights by firm size are given by the ratio between the total number of firms in the economy (from Social Security Records) and the number of firms in the Company Accounts Data Service. One asterisk denotes significance at 5\%; two asterisks denote significance at $1 \%$; three asterisks denotes significance at $0.1 \%$.

\section{The Role of Financial Market Imperfections}

Labor and financial market imperfections are likely to interact. The previous section confirms this intuition suggesting that stricter EPL reduces firms' ability to access the credit market. Thus, on the one side, stricter EPL seems to make credit market imperfections more severe, on the other side, ill-functioning credit markets may exacerbate the effects of stricter labor markets regulations.

To explore this idea, this section investigates whether the effect of the reform on capital deepening is different depending on the availability of credit. The idea is that credit constrained firms belonging to the treatment group may not be able to react to the change in EPL and engage in capital deepening as much as unconstrained firms.

As mentioned in the introduction, there are not many papers that empirically investigate the joint influence of imperfect financial and labor markets on capital. Notable exceptions are Claessens and Ueda (2008), Calcagnini et al. (2009) and Cingano et al. (2010). Similarly, the theoretical impact of credit and labor market imperfections on capital investment has been analyzed only in Rendon (2004), who shows that job creation is limited by financing constraints even in the presence of a flexible labor market, and in Wasmer and Weil (2002).

Most empirical studies, in the tradition of Fazzari, Hubbard and Petersen (1988), focus on the impact of financing constraints on investment and regress a measure of investment on a measure of investment opportunities (Tobin's q) as well as a measure of cash flow, i.e. they estimate the 
sensitivity of investment to cash flow conditional on $q$. This empirical specification implies that, even in the absence of financing constraints, investment is subject to adjustment costs that prevent the capital stock adjusting continuously to maintain equality between the marginal revenue product and the user cost of capital. Measurement of Tobin's $q$ requires knowledge of the market value of the firm. This piece of information is not available in our data, as the vast majority of the firms included in our sample is unlisted. For this reason, our empirical specification uses Return On Assets (ROA) as a measure of investment opportunities.

Following the literature, we measure internal funds using cash-flow normalized by fixed assets $\left(C F_{j p r e}=\frac{\text { cash flow } w_{\text {jpre }}}{\text { FixedAssets }}\right)$. In Table 5 we have seen that the reform itself may affect firms' access to credit. Therefore, in order to minimize endogeneity issues we measure both cash-flow and fixed assets in the pre-reform period and consider the availability of internal resources as a firm fixed characteristic.

The triple difference specification is therefore:

$$
\begin{aligned}
\log \left(k_{j t}\right)= & \beta^{\prime} X_{j t}+\delta_{0} \text { Post }+\delta_{1} D_{j t}^{S}+\delta_{2}\left(D_{j t}^{S} \times \text { Post }\right)+\delta_{3}\left(C F_{j p r e}\right)+ \\
& +\delta_{4}\left(D_{j t}^{S} \times C F_{j p r e}\right)+\delta_{5}\left(C F_{j p r e} \times \text { Post }\right)+\delta_{6}\left(C F_{j p r e} \times D_{j t}^{S} \times \text { Post }\right)+v_{j}+u_{j t}
\end{aligned}
$$

The triple interaction term $C F_{j p r e} \times D_{j t}^{S} \times$ Post pins down the effect of the change in EPL in firms with different levels of internal resources. We expect this interaction term to be positive because we expect capital deepening to take place more easily in firms with higher levels of internal resources.

We also run quantile regressions to check whether the impact of internal resources is different for firms at different points of the log capital distribution. Liquidity may indeed be more important for low-capital intensity firms, which are possibly subject to stricter financial constraints due to the scarce availability of collateralizable assets.

Let $Q_{\theta}\left(\log \left(k_{j t}\right) \mid X_{j t}\right)$ for $\theta \in(0,1)$ denote the $\theta^{\text {th }}$ quantile of the distribution of $\log \left(k_{j t}\right)$ conditional on firm characteristics included in the matrix $X_{j t}{ }^{13}$ The model of the conditional quantile is:

$$
\begin{aligned}
Q_{\theta}\left(\log \left(k_{j t}\right) \mid X_{j t}\right)= & \beta_{\theta}^{\prime} X_{j t}+\gamma R O A_{j p r e}+\delta_{1 \theta} D_{j t}^{S}+\delta_{2 \theta}\left(D_{j t}^{S} \times \text { Post }\right)+\delta_{3 \theta} C F_{j p r e}+ \\
& +\delta_{4 \theta}\left(D_{j t}^{S} \times C F_{j p r e}\right)+\delta_{5 \theta}\left(C F_{j p r e} \times \text { Post }\right)+\delta_{6 \theta}\left(C F_{j p r e} \times D_{j t}^{S} \times \text { Post }\right)+v_{j}
\end{aligned}
$$

\footnotetext{
${ }^{13}$ We include the same controls as in Equation (3), plus firm ROA (measured in the pre-reform period) to account for firm profitability. Notice that despite pre-reform firm ROA being a time-invariant firm characteristic, in the non-linear quantile regression model its effect is not absorbed by the firm fixed effect.
} 
TABLE 10. Differential impact of the reform on log capital stock depending on pre-reform cash-flow

\begin{tabular}{|c|c|c|c|c|c|c|}
\hline & "(1) & 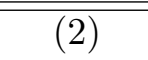 & 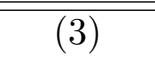 & 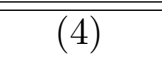 & 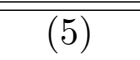 & 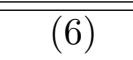 \\
\hline & Mean & \multicolumn{5}{|c|}{ Quantile regressions } \\
\hline & Regression & 10 & 25 & 50 & 75 & 90 \\
\hline Small firm $\times$ Post 90 & $\begin{array}{c}0.043^{* * *} \\
(0.012)\end{array}$ & $\begin{array}{c}0.076^{* * *} \\
(0.013)\end{array}$ & $\begin{array}{c}0.027^{* * *} \\
(0.007)\end{array}$ & $\begin{array}{c}0.030^{* * *} \\
(0.005)\end{array}$ & $\begin{array}{l}0.018^{* *} \\
(0.007)\end{array}$ & $\begin{array}{c}0.009 \\
(0.015)\end{array}$ \\
\hline $\begin{array}{l}\text { Cash-Flow } / \text { FA } \times \text { Small firm } \times \\
\text { Post } 90 \text { dummy }\end{array}$ & $\begin{array}{c}0.017 \\
(0.018)\end{array}$ & $\begin{array}{l}0.035^{* *} \\
(0.012)\end{array}$ & $\begin{array}{c}0.017 \\
(0.009)\end{array}$ & $\begin{array}{c}0.020^{* *} \\
(0.007)\end{array}$ & $\begin{array}{c}0.021 \\
(0.012)\end{array}$ & $\begin{array}{l}-0.000 \\
(0.023)\end{array}$ \\
\hline Observations & 17,055 & 17,055 & 17,055 & 17,055 & 17,055 & 17,055 \\
\hline
\end{tabular}

Notes: Robust standard errors clustered by firm in parentheses in column 1. Bootstrapped standard errors clustered by firm in columns 2-6 (100 replications). All specifications include firm ROA measured in the pre-reform period, a third degree polynomial in the size of the firm, firm fixed effects, sector-year dummies, a full set of interaction terms between the ratio of cash-flow to fixed assets (both measured in the pre-reform period), the Post 1990 dummy and the small firm dummy. One asterisk denotes significance at 5\%; two asterisks denote significance at 1\%; three asterisks denotes significance at $0.1 \%$.

As for equation 2, we assume that the firm fixed effects are pure location shifters (i.e. they are not quantile-specific), and estimate the above quantile model using the two-step procedure suggested by Canay (2011).

Table 10 shows results from the estimation of equation (3) in the first column and of equation (4) in the remaining columns. The estimates indicate that, on average, the reform induces capital deepening in small compared to large firms (consistently with the results in Table 3), with no significant differential effects of cash-flow (column 1). The remaining columns display a pattern similar to the one in Table 4 : the effect of the reform on capital deepening is highest - with a coefficient equal to 0.035 - at the $10^{\text {th }}$ percentile and then decreases along the distribution of log capital reaching zero at the $90^{\text {th }}$ percentile. In particular, a one standard deviation increase in the ratio of Cash-flow to Fixed Assets (equal to 0.22 , see Table 1) raises the capital stock by $3.5 \%$ at the tenth percentile of the $\log$ capital distribution.

This result suggests that large amounts of liquidity ease the response of firms with a relatively low capital stock to the change in EPL. The reason may be that firms with little collateralizable capital may find it difficult to borrow and therefore need to rely on internal liquid resources to raise the capital stock in response to the increase in EPL. The general implication is that financial market imperfections hinder firms' reaction to the increase in firing costs and therefore amplify the allocative inefficiencies due to stricter EPL. 


\section{Conclusion}

The average firm size in Italy is approximately half that of the European Union and expensive EPL for firms larger than 15 is often indicated as one of the factors responsible for such a skewed size distribution. This claim does not seem to be confirmed in the data because there is no lump of firms at 15 (see Figure 1). A large literature has underlined the large differences in EPL regulations at given firm thresholds (there exists different thresholds in different countries) yet there is a puzzle given by the apparent inconsistency between a large difference in EPL and the continuity of the firm size distribution (see also Bauer et al. (2007) for Germany). Leonardi and Pica (2013) show that some of the adjustment takes place through lower wages; Schivardi and Torrini (2008) explain the nonexistence of a large lump at 15 by the fact that firms choose their size on the basis of several factors and not only on the basis of EPL and by the fact the firms change their size often from one year to the next (using irregular employment or fixed-term employees) and find themselves at least temporarily with 16 employees when they are on a growth trend. We fill a gap in the literature making use of a data set with information on capital stock which is potentially a fundamental adjustment variable.

Fixed effects estimates show a positive effect of the reform on capital deepening, thus pointing towards capital-labor substitution. Substitution between capital and labor is concentrated in lowcapital intensive firms, possibly because firms with a high share of labor costs are hit harder by the reform. Among the firms with low capital-labor ratios, we find that the effect is less pronounced for firms with low internal liquid resources, plausibly because these firms have little capital to pledge as collateral against lenders and no internal resources to rely upon. Finally, our results indicate that, after the reform, small firms are less likely to access the credit market relative to larger firms. 


\section{References}

[1] Acemoglu, Daron, (2002), Directed Technical Change, The Review of Economic Studies, Vol. 69, No. 4 , pp. $781-809$

[2] Acemoglu, Daron, (2003), Labor- and Capital-Augmenting Technical Change, Journal of the European Economic Association, Vol. 1, No. 1, pp. 1-37

[3] Alesina, A. and Joseph Zeira, (2006), Technology and Labor Regulations, Harvard Institute of Economic Research DP 2123.

[4] Autor, David H., (2003), Outsourcing at Will: The Contribution of Unjust Dismissal Doctrine to the Growth of Employment Outsourcing, Journal of Labor Economics, 21(1), January, 1-42.

[5] Autor, David H., John J. Donohue and Stewart J. Schwab, (2004), The Employment Consequences of Wrongful-Discharge Laws: Large, Small, or None at All?, American Economic Review Papers and Proceedings, 93(2), May, 440-446.

[6] Autor, David H., John J. Donohue and Stewart J. Schwab, (2006), The Costs of WrongfulDischarge Laws, Review of Economics and Statistics, 88(2), May, 211-231.

[7] Autor, David H., William R. Kerr and Adriana D. Kugler, (2007), Do Employment Protections Reduce Productivity? Evidence from U.S. States, The Economic Journal, 117, F189-F271.

[8] Bauer, Thomas K., Stefan Bender and Holger Bonin, (2007). Dismissal Protection and Worker Flows in Small Establishments. Economica, 296(74): 804-821.

[9] Bentolila, Samuel and Bertola, Giuseppe, (1990), Firing Costs and Labour Demand: How Bad Is Eurosclerosis?, Review of Economic Studies, vol. 57(3), pages 381-402.

[10] Bentolila, Samuel and Juan José Dolado (1994). Labour flexibility and wages: lessons from Spain, Economic Policy, 18, 53-100.

[11] Bertola, Giuseppe, and Richard Rogerson, (1997), Institutions and Labour Reallocation, European Economic Review, 41(6), June, 1147-1171.

[12] Bertrand, Marianne, Esther Duflo and Sendhil Mullainathan, (2004), How Much Should We Trust Differences-In-Differences Estimates? The Quarterly Journal of Economics, 119(1): 249-275. 
[13] Bird, Robert C. and John D. Knopf, (2009), Do Wrongful Discharge Laws Impair Firm Performance?, Journal of Law and Economics, 52(2), 197-222.

[14] Boeri, T., and Juan F. Jimeno, (2005), The Effects of Employment Protection: Learning from Variable Enforcement, European Economic Review, 49(8), 2057-2077

[15] Borgarello, A., Pietro Garibaldi and Lia Pacelli, (2004), Employment Protection Legislation and the Size of Firms, Il Giornale degli Economisti, 63(1), 33-66.

[16] Caballero, Ricardo J. and Mohammad Hammour, (1998), Jobless Growth: Appropriability, Factor Substitution and Unemployment. Carnegie-Rochester Conference Proceedings, 48, pp. 51-94.

[17] Caggese, Andrea and Vicente Cuñat, (2008), Financing Constraints and Fixed-Term Employment Contracts, Economic Journal, 118(533), 2013-2046.

[18] Calcagnini, Giorgio, Germana Giombini and Enrico Saltari, (2009), Financial and labor market imperfections and investment, Economics Letters, 102(1), 22-26.

[19] Canay, Ivan A., (2011), A simple approach to quantile regression for panel data, Econometrics Journal, 14, 368-386

[20] Cervini Plá, María, Xavier Ramos and José Ignacio Silva, (2010), Wage Effects of Non-Wage Labour Costs, IZA DP. 4882.

[21] Cingano, Federico, Marco Leonardi, Julián Messina and Giovanni Pica, (2010), The Effect of Employment Protection Legislation and Financial Market Imperfections on Investment: Evidence from a Firm-Level Panel of EU Countries, Economic Policy, Volume 25, Issue 61, 117-163.

[22] Claessens, Stijn, and Kenichi Ueda, (2008), Banks and Labor as Stakeholders: Impact on Economic Performance, IMF Working Papers 08/229, International Monetary Fund.

[23] Fazzari, Steven, R. Glenn Hubbard and Bruce Petersen (1988): Financing Constraints and Corporate Investment. Brookings Papers on Economic Activity, 141-195.

[24] Garibaldi, Pietro, and Gianluca Violante, (2005), The Employment Effects of Severance Payments with Wage Rigidities, Economic Journal, 115 (October), 799-832.

[25] Janiak, Alexandre and Etienne Wasmer, (2012), EPL and capital-labor ratios, Universidad de Chile, Documentos de Trabajo 288. 
[26] Koeniger Winfried and Marco Leonardi, (2007), Capital Deepening and Wage Differentials: Germany vs. US., Economic Policy, 22(49), 71-116.

[27] Kugler, Adriana, and Giovanni Pica, (2008), Effects of Employment Protection on Worker and Job Flows: Evidence from the 1990 Italian Reform, Labour Economics, Volume 15, Issue 1, pp. $78-95$.

[28] Kugler, A. and Gilles Saint-Paul, (2004), How Do Firing Costs Affect Worker Flows in a World with Adverse Selection?, Journal of Labor Economics, 22(3), 553-584.

[29] Lazear, Edward, (1990), Job Security Provisions and Employment, Quarterly Journal of Economics, 105(3), 699-726.

[30] Leonardi, Marco and Giovanni Pica, (2013), Who Pays for it? The Heterogeneous Wage Effects of Employment Protection Legislation, Economic Journal, forthcoming.

[31] Marinescu, Ioana, (2009), Job Security Legislation and Job Duration: Evidence from the U.K., Journal of Labor Economics, vol. 27, no. 3, 475-486.

[32] Martins, Pedro S., (2009). Dismissals for Cause: The Difference That Just Eight Paragraphs Can Make, Journal of Labor Economics, 27(2), 257-279.

[33] Rendon, Sílvio, (2004), Job Creation and Investment in Imperfect Capital and Labor Markets, Economic Working Papers at Centro de Estudios Andaluces E2004/35, Centro de Estudios Andaluces.

[34] Schivardi, Fabiano, and Roberto Torrini, (2008), Identifying the effects of firing restrictions through size-contingent differences in regulation, Labour Economics, 15(3), 482-511.

[35] Skedinger, Per, (2011), Employment Consequences of Employment Protection Legislation, Nordic Economic Policy Review, 1, 45-83.

[36] Stole, Lars A.and Jeffrey Zwiebel, (1996a), Intra-Firm Bargaining under Non-Binding Contracts, The Review of Economic Studies, 63, 375-410.

[37] Stole, Lars A.and Jeffrey Zwiebel, (1996b), Organizational Design and Technology Choice under Intrafirm Bargaining, The American Economic Review, 86(1), 195-222. 
[38] Van der Wiel, Karen (2010). Better Protected, Better Paid: Evidence on how Employment Protection Affects Wages, Labour Economics, 7(1), 829-849. 


\section{A Additional Tables}

To verify if firms sort according to pre-existing observable and unobservable characteristics, we first average firm capital stock before 1989 (before the reform) and then use this time-invariant variable (which we call fixed effect) as one of the determinants of the firm probability of growing. We exploit the unique opportunity of observing capital stock to build a variable which should capture hitherto unobserved firms' characteristics. The probit regression is of the form:

$$
\begin{aligned}
d_{j t}= & \beta^{\prime} X_{j t}+\delta_{0} \text { Post }+\delta_{1} \text { Sizedummy } y_{j-1}+\delta_{2} F E_{j}+\alpha_{0}\left(\text { Sizedummy } y_{j t-1} \times \text { Post }\right) \\
& +\alpha_{1}\left(F E_{j} \times \text { Post }\right)+\alpha_{2}\left(\text { Sizedummy } y_{j-1} \times \text { Post } \times F E_{j}\right)+\varepsilon_{j t},
\end{aligned}
$$

where $d_{j t}=1$ if firm $j$ in year $t$ has a larger size than in $t-1$. The term Sizedummy $y_{j-1}$ denotes a set of firm size dummies while the variable Post takes the value of one from 1991 . The term $F E_{j}$ denotes the estimated firm fixed effects. The matrix $X_{j t}$ includes a quadratic in firms' age, year dummies, sector dummies and a polynomial in lagged firm size.

Column 1 of Table A.1 shows that on average firms just below 15 employees are about $4 \%$ less likely to grow than larger firms (significant coefficient on Dummy 15). These results are consistent with Schivardi and Torrini (2008), Borgarello, Garibaldi and Pacelli (2004) who find that more stringent job security provisions hamper firm growth. They find that the discontinuous change in EPL at the 15 employees threshold reduces by $2 \%$ the probability that firms pass the threshold. Column 2 shows that the effect is not significantly different before and after the reform (insignificant coefficient on Post $1990 \times$ Dummy 15). Column 3 shows that once we control for average capital stock pre-reform, the coefficient on Dummy 15 becomes non significant indicating that omitting capital in this growth regressions may yield biased results as firms just below the threshold react to changes in EPL also through capital choices. Finally, Column 4 indicates that the effect is similar for firms with different average pre-reform capital stocks, as the coefficient of the triple interaction Post $1990 \times$ Firms Fixed Effect $\times$ Dummy 15 is not significantly different from zero. We conclude that there is no evidence of firm sorting around the time of the reform at least according to their pre-determined capital stock. 
TABle A.1. Firm Sorting

\begin{tabular}{|c|c|c|c|c|}
\hline & $(1)$ & $(2)$ & $(3)$ & $(4)$ \\
\hline Dummy 13 & $\begin{array}{c}-0.0394^{* * *} \\
(0.00660)\end{array}$ & $\begin{array}{c}-0.0340^{* * *} \\
(0.0100)\end{array}$ & $\begin{array}{c}0.0846 \\
(0.0821)\end{array}$ & $\begin{array}{l}0.0857 \\
(0.123)\end{array}$ \\
\hline Dummy 14 & $\begin{array}{c}-0.0428^{* * *} \\
(0.00647)\end{array}$ & $\begin{array}{c}-0.0425^{* * *} \\
(0.0101)\end{array}$ & $\begin{array}{l}-0.0577 \\
(0.0496)\end{array}$ & $\begin{array}{c}-0.113^{*} \\
(0.0469)\end{array}$ \\
\hline Dummy 15 & $\begin{array}{c}-0.0394^{* * *} \\
(0.00660)\end{array}$ & $\begin{array}{c}-0.0477^{* * *} \\
(0.00984)\end{array}$ & $\begin{array}{l}-0.0664 \\
(0.0482)\end{array}$ & $\begin{array}{c}-0.129^{* * *} \\
(0.0385)\end{array}$ \\
\hline Firms Fixed Effect & & & $\begin{array}{c}0.00468 \\
(0.00393)\end{array}$ & $\begin{array}{c}0.00446 \\
(0.00558)\end{array}$ \\
\hline Firms Fixed Effect $\times$ Dummy 13 & & & $\begin{array}{c}-0.0183 \\
(0.00968)\end{array}$ & $\begin{array}{l}-0.0174 \\
(0.0143)\end{array}$ \\
\hline Firms Fixed Effect $\times$ Dummy 14 & & & $\begin{array}{l}0.00241 \\
(0.0103)\end{array}$ & $\begin{array}{c}0.0167 \\
(0.0159)\end{array}$ \\
\hline Firms Fixed Effect $\times$ Dummy 15 & & & $\begin{array}{c}0.00478 \\
(0.0104)\end{array}$ & $\begin{array}{c}0.0216 \\
(0.0163)\end{array}$ \\
\hline Post $1990 \times$ Firms Fixed Effect & & & & $\begin{array}{c}0.000452 \\
(0.00710)\end{array}$ \\
\hline Post $1990 \times$ Dummy 13 & & $\begin{array}{l}-0.0113 \\
(0.0146)\end{array}$ & & $\begin{array}{c}0.00469 \\
(0.129)\end{array}$ \\
\hline Post $1990 \times$ Dummy 14 & & $\begin{array}{c}-0.000663 \\
(0.0160)\end{array}$ & & $\begin{array}{c}0.220 \\
(0.230)\end{array}$ \\
\hline Post $1990 \times$ Dummy 15 & & $\begin{array}{c}0.0184 \\
(0.0180)\end{array}$ & & $\begin{array}{c}0.283 \\
(0.251)\end{array}$ \\
\hline Post $1990 \times$ Firms Fixed Effect $\times$ Dummy 13 & & & & $\begin{array}{r}-0.00278 \\
(0.0193)\end{array}$ \\
\hline Post $1990 \times$ Firms Fixed Effect $\times$ Dummy 14 & & & & $\begin{array}{c}-0.0247 \\
(0.0209)\end{array}$ \\
\hline Post $1990 \times$ Firms Fixed Effect $\times$ Dummy 15 & & & & $\begin{array}{c}-0.0266 \\
(0.0212)\end{array}$ \\
\hline Observations & 15,638 & 15,638 & 13,603 & 13,603 \\
\hline
\end{tabular}

Notes: The dependent variable is a dummy that takes the value of 1 if in firm $j$ employment at time $t$ is one unit larger than employment at time $t-1$, and 0 otherwise. Firms between 10 and 20 workers are included. All specifications include a third degree polynomial in lagged firm size, a quadratic in firms' age, sector dummies and year dummies. One asterisk denotes significance at $5 \%$; two asterisks denote significance at $1 \%$; three asterisks denotes significance at $0.1 \%$. 